\title{
DEVELOPMENT OF STUDENTS' UNDERSTANDING OF EXPONENTIAL BASED ON COGNITIVE STYLE
}

\author{
Oleh: \\ Eka Novi Arisandi ${ }^{1}$, Yusuf Fuad ${ }^{2}$ \\ ${ }^{1,2}$ Mathematics Department, Universitas Negeri Surabaya \\ 르akarisandi@mhs.unesa.ac.id \\ 2yusuffuad@unesa.ac.id
}

\begin{abstract}
Abstrak - Pemahaman adalah faktor penting dalam pembelajaran matematika. Salah satu teori tentang pemahaman adalah Teori Pirie-Kieren. Teori Pirie-Kieren menjelaskan tentang pertumbuhan pemahaman. Faktor internal yang mempengaruhi pemahaman siswa adalah gaya kognitif. Ada berbagai jenis gaya kognitif, salah satunya adalah gaya kognitif pemahaman konsep berbasis waktu, yaitu gaya kognitif Reflektif-Impulsif. Tujuan dari penelitian ini adalah untuk menggambarkan tingkat pemahaman siswa SMP tentang perpangkatan berdasarkan teori Pirie-Kieren dan gaya kognitif reflektif-impulsif. Penelitian ini menggunakan Matching Familiar Figure Test (MFFT), Tes Kemampuan Matematika (TKM) dan Tes Pemahaman Materi Perpangkatan (TPMP) dan juga pedoman wawancara untuk menggambarkan tingkat pemahaman siswa tentang Perpangkatan berdasarkan teori Pirie-Kieren. Subjek penelitian adalah siswa kelas dua. Berdasarkan hasil pemberian TPMP diperoleh 7 siswa dengan gaya kognitif reflektif dan 10 siswa dengan gaya kognitif impulsif. Berdasarkan hasil pemberian TKM, dari 7 siswa dengan gaya kognitif reflektif diperoleh 4 siswa dengan kemampuan matematika tinggi dan 2 siswa dengan kemampuan matematika rendah. Pada gaya kognitif impulsif, 10 siswa memperoleh 3 siswa dengan kemampuan matematika tinggi, seorang siswa dengan kemampuan matematika sedang dan 6 siswa dengan kemampuan matematika rendah. Selanjutnya, dengan mempertimbangkan nilai hasil TPMP dan kesukarelaan siswa, dipilih 4 subjek penelitian dengan kemampuan matematika tinggi, ada 2 subjek dengan gaya kognitif reflektif dan 2 subjek dengan gaya kognitif impulsif. Hasil penelitian menunjukkan bahwa tingkat pemahaman siswa SMP tentang perpangkatan berdasarkan teori Pirie-Kieren dan gaya kognitif reflektifimpulsif adalah, (1) siswa dengan gaya kognitif reflektif dapat mencapai tingkat observing padalevel pemahaman oleh Teori Pirie-Kieren dan (2) siswa dengan gaya kognitif impulsif juga mencapai level observing pada level pemahaman oleh Teori Pirie-Kieren.
\end{abstract}

Kata kunci - Pemahaman, Perpangkatan, Teori Pirie-Kirien, Reflektif-Impulsif

Abstract - Understanding is an important factor in mathematics teaching learning. One of theories about understanding is Pirie-Kieren's Theory. Pirie-Kieren's theories explain about growth of understanding. Internal factors that influence students' understanding include cognitive style. There are various types of cognitive styles, one of which is a time-based cognitive style of concept understanding, namely the Reflective-Impulsive cognitive style. The purpose of this study is to describe the level of junior high school students' understanding of the exponential based on of Pirie-Kieren's theory and reflective-impulsive cognitive style. This research used Matching Familiar Figure Test (MFFT), Mathematics Ability Test (TKM) and Departure Material Understanding Test (TPMP) and also interview guidelines to describe the level of students' understanding of exponential based on Pirie-Kieren's theory. The subjects of the study were students in second grade. Based on the results of giving TPMP obtained 7 students with reflective cognitive style and 10 students with impulsive cognitive style. Based on the results of giving TKM, from 7 students with reflective cognitive styles obtained 4 students with high mathematical abilities and 2 students with low mathematical abilities. In impulsive cognitive style, 10 students obtained 3 students with high mathematical ability, a student with moderate mathematical ability and 6 students with low mathematical ability. Furthermore, taking into account the value of the results of TPMP and students' willingness to choose 4 subjects with high mathematical ability, there are 2 subjects with reflective cognitive style and 2 subjects with impulsive cognitive style. The results showed that the level of junior high school students' understanding of the material in terms of Pirie-Kieren's theory and reflective-impulsive cognitive style were, (1) students with reflective cognitive style could reach the observing level at the level of understanding of Pirie-Kieren's theory and (2) students with impulsive cognitive style can reach the level of observing at the level of understanding of the Pirie-Kieren theory.

Keywords - Understanding, Exponential, Pirie-Kieren's Theory, Reflective-Impulsive. 


\section{INTRODUCTION}

Understanding is an important thing to consider in learning. For students, the understanding of a material is important because it is used as a basis for understanding the next material. Whereas for a teacher one indicator of the achievement or success of learning is seen from the level of student understanding of the material that has been given. Just the same as the opinion of Garagae (2012) that students' understanding of mathematics is a sign of achievement-having met the goals of teaching. This is in line with NCTM (2000), Students have to learn mathematics with understanding and construct the concept by using their experience. From this quote, the goal of learning is not only students are able to memorize formulas or are able to calculate without understanding the meaning of the formulas that they can, but students must understand and understand the concepts and the relationship of the concepts themselves from each material taught.

Pirie and Kieren's (1994) theories explain the growth in understanding as a process that is whole, dynamic, leveled but not linear, and never ends. The level of understanding according to this theory consists of eight levels, namely primitive knowing, image-making, image-having, property noticing, formalizing, observing, structuring, and inventorying. Based on this theory, growth in understanding does not always go well in the same direction. A person's understanding often returns to the previous level to further advance to the next level of understanding called folding back.

Parameswaran (2010) states that Pirie-Kieren's theory expresses understanding as a process of constructing personal knowledge. Mousley (2004) explained that understanding is developed, developed and organized as a result of cognitive interactions between sensory experiences and existing schemes. Based on this definition, understanding is not directly accepted by students, but understanding is formed or built by students themselves through certain stages.

Pinahayu (2015), there were still many errors found by students in solving exponent problem problems. One example problem is $2^{3} \times 4^{3}$. Students solve these problems by multiplying the principal numbers and adding up the exponent. Furthermore, Pinahayu (2015) revealed that students experience difficulties due to a lack of understanding of concepts. Research conducted by Mokwebu (2013) also revealed that students who were the subjects of their research were not quite right in interpreting $2 \mathrm{a}^{2}$. Walle, et al. (2013) states a common mistake that occurs in this exponent material is students think that the exponent is two values as factors, for example, $5^{3}=5 \times 3$. Weber
(2002) explained that students often forget the characteristics of exponents shortly after they learn them and rarely can explain why they are true.

Student understanding is influenced by several factors, both external and internal factors. External factors that influence students 'understanding are the way teachers teach material, while internal factors are students' cognitive styles. Following Abubakar (2016) which says that cognitive style is a characteristic of every individual in paying attention and understanding information and interpreting a situation. Cognitive styles are classified into several types, one of which is reflective-impulsive cognitive style. Reflectiveimpulsive cognitive style is a type of cognitive style based on the time of understanding a concept. Familiar Figure Test (MFFT) is a test used to determine students' cognitive styles, including reflective or impulsive cognitive styles.

Many studies related to the understanding of a material in mathematics that uses a review of reflective and impulsive cognitive styles. Then, there is research on understanding the exponent material and analyzed using Pirie and Kieren's theory in terms of gender differences by Syafiqoh, et al. (2018) which states that male and female students alike reach the level of formalizing understanding.

Description above raises the question of how the level of student understanding of the material when analyzed using the theory of Pirie and Kierin but in terms of reflective-impulsive cognitive style. So researchers conducted to determine Development of Student Understanding of Exponential Based on Cognitive Style.

\section{METHODS}

This research is a descriptive study with a qualitative approach. The purpose of this study is to describe the level of junior high school students' understanding of the material in terms of PirieKieren's theory and reflective-impulsive cognitive style.

This research used supporting instruments in the form of Matching Familiar Figure Test (MFFT), Mathematics Ability Test (TKM) and Departure Material Understanding Test (TPMP) and interview guidelines to describe the level of students' understanding of the material based on PirieKieren's theory.

The study was conducted at SMP Negeri 1 Nganjuk in the 2018/2019 school year. The subjects of the study were students in 8th grade. Purposefully chosen class VIII-8 as a class of research subjects from 9 existing class VIII. MFFT is used to get students with reflective cognitive style and impulsive cognitive style. From the 26 students 
who were given the MFFT test, it was found that 7 students were included in the reflective cognitive style, 10 students were impulsive cognitive style, and the rest belonged to the group of "fast-right" or "slow-wrong", but both of that group were not considered in this research.

Then used TKM for grouping students based on their Mathematics Ability. Based on TKM, 4 students with high mathematical abilities and 3 students in the low category in reflective cognitive style. In impulsive cognitive style, I found 3 students with high mathematical abilities, a student in the medium category, and 6 students in the low category. Then a group with high mathematical ability is chosen, because we hope can be obtained the data on the test of TPMP. In the group of reflective students with high mathematical abilities, the scores obtained were $85,95,95$, and 95 . While, in the impulsive group of students obtained 85, 90, and 95. In the group of students with high mathematical abilities, students with score greater or equal to 90 were selected.

The last is given TPMP to 26 students for obtained the information about student's understanding of exponential. From that,we obtained the subject with score 65 and 82 at reflective cognitive style, then the subject with score 69 and 78 at impulsive cognitive style. Finally, there were 4 subjects with a high mathematical ability with score greater or equal to 90, 4 subjects consisted of 2 reflective cognitivestyle subjects with TPMP values of 65 and 82 then impulsive cognitive-style subjects with TPMP values of 69 and 78. Data analysis in this study consists of three steps namely data reduction, data display, and conclusion.

\section{RESULTS AND DISCUSSIONS}

Research data collection activities carried out in several stages, namely: (1) Provision of cognitive style tests (MFFT), (2) Provision of TKM, (3) Provision of material understanding tests (TPMP), and (4) Interviews. The research data was collected from 14th May 2019 until 1th July The following is a list of research subjects obtained, presented in Table 1.

Tabel 1. Subjects of Research

\begin{tabular}{ccccc}
\hline Label & Cognitive Style & Score TKM & Category & Score TPMP \\
\hline SR1 & Reflective & 95 & High & 82 \\
SR2 & Reflective & 95 & High & 65 \\
SI1 & Impulsive & 95 & High & 78 \\
SI2 & Impulsive & 90 & High & 69 \\
\hline
\end{tabular}

To analyze the development understanding of students on exponential, this research used this indicators which is adapted from Pirie-Kieren (1994).

Tabel 2. Indicators of Level Understanding by Pirie-Kieren (1994)

\begin{tabular}{lll}
\hline \multicolumn{1}{c}{ Level } & \multicolumn{1}{c}{ Indicators } & Code \\
\hline Primitive knowing & $\begin{array}{l}\text { Can describe the definition of exponent } \\
\text { by describing the form of numbers into } \\
\text { repetitive multiplication. }\end{array}$ & PK \\
\hline Image Making & $\begin{array}{l}\text { Can do physical activity in the form of } \\
\text { writing, crossing out, calculating to get } \\
\text { or understand the concept of } \\
\text { multiplication and division of numbers. }\end{array}$ & IM \\
\hline Image Having & $\begin{array}{l}\text { Can give other examples of } \\
\text { multiplication operations and division } \\
\text { of numbers with varying bases. }\end{array}$ & IH \\
\hline Property Noticing & $\begin{array}{l}\text { Can explain the differences in } \\
\text { multiplication and division operations } \\
\text { on numbers. }\end{array}$ & PN \\
\hline Formalizing & $\begin{array}{l}\text { Can write the concept of multiplication } \\
\text { and division of numeric numbers into } \\
\text { the general form using certain } \\
\text { variables. }\end{array}$ & F1 \\
\hline
\end{tabular}


Being able to apply the nature of multiplication and division of exponents in solving related problems.

\begin{tabular}{lll}
\hline Observing & $\begin{array}{l}\text { Able to reflect and use the formal } \\
\text { understanding and can make } \\
\text { predictions without the need for certain } \\
\text { actions. }\end{array}$ & OB \\
\hline Structuring & $\begin{array}{l}\text { Can prove the nature of multiplication } \\
\text { and division of exponent based on } \\
\text { logical and structured arguments. }\end{array}$ & ST \\
\hline Inventising & $\begin{array}{l}\text { Can create new questions that can grow } \\
\text { into a new concept. }\end{array}$ & IN \\
\hline
\end{tabular}

Based on these indicators researcher made question to explore students' understanding about exponential. The following are questions that have been made by researchers:

Tabel 3. Questions of Level Understanding Pirie-Kieren

\begin{tabular}{|c|c|}
\hline No. & Questions \\
\hline 1. & $\begin{array}{l}\text { Complete the points below. } \\
\text { If given } 2^{3}=\ldots \times \ldots \times \ldots=\ldots, \text { then } 2 \text { as } \ldots \text { and } 3 \text { as } \ldots\end{array}$ \\
\hline 2. & $\begin{array}{l}\text { Determine the outcome of these exponential in the simplest form of exponential. } \\
\begin{array}{ll}\text { a. } 2^{3} \times 2^{2}=\ldots & \text { d. } 2^{3} \div 2^{2}=\ldots \\
\text { b. } 3^{5} \times 3^{4}=\ldots & \text { e. } 3^{5} \div 3^{4}=\ldots \\
\text { c. } 6^{2} \times 2^{1}=\ldots & \text { f. } 6^{2} \div 2^{1}=\ldots \\
\text { Explain your procedure! } & \end{array}\end{array}$ \\
\hline 3. & $\begin{array}{l}\text { Choose } 1 \text { multiplication problem and } 1 \text { division problem between the following } 6 \\
\text { questions which you think is the easiest. Then work on and state the results in the } \\
\text { simplest exponential. } \\
\begin{array}{l}\text { a. } 2^{2020} \times 2^{2019}=\ldots \\
\text { b. } 3^{2020} \times 2^{2019}=\ldots \\
\text { c. } 2020^{3} \times 2019^{2}=\ldots \\
\text { d. } 2^{2020} \div 2^{2019}=\ldots \\
\text { e. } 3^{2020} \div 2^{2019}=\ldots \\
\text { f. } 2020^{3} \div 2019^{2}=\ldots\end{array}\end{array}$ \\
\hline 4. & What do you know about multiplication operations and division of exponential? \\
\hline 5. & $\begin{array}{l}\text { If } a, b, c \text { are positive integers and } b>c, \text { determine the result of: } \\
\begin{array}{l}\text { a. } \quad a^{b} \times a^{c}=\ldots \\
\text { b. } \quad a^{b} \div a^{c}=\ldots\end{array}\end{array}$ \\
\hline 6. & Determine the result of $\frac{2^{5} \times 2^{8} \times 2}{2^{7} \div 2^{3} \div 2^{2}}=\ldots$ \\
\hline 7. & $\begin{array}{l}\text { Observe the following division and multiplication process. Is it already correct? If it's } \\
\text { still wrong, show the location of the error and provide the correct answer. } \\
\text { a. } \frac{3^{13}}{3^{5}}=3^{\frac{13}{5}}=3^{8} \\
\text { b. } 3^{6} \times 3^{4}=(3 \times 3)^{6+4}=9^{10}\end{array}$ \\
\hline 8. & 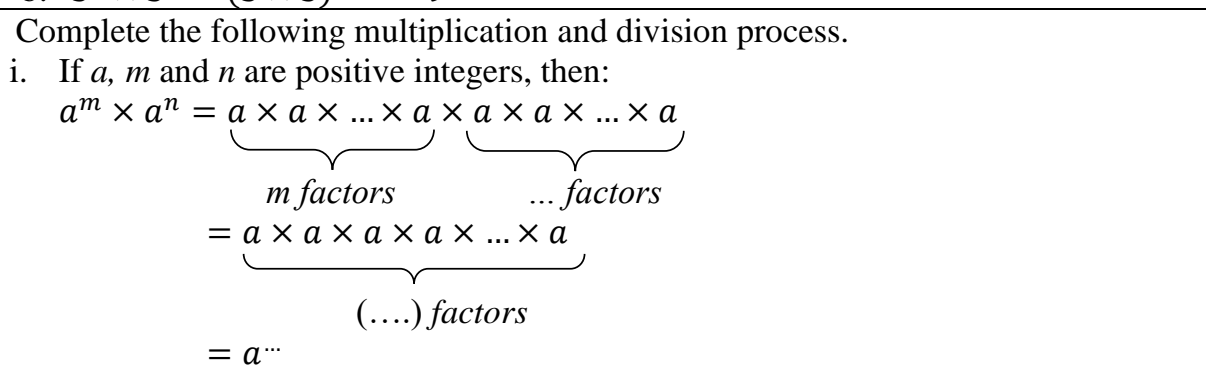 \\
\hline
\end{tabular}




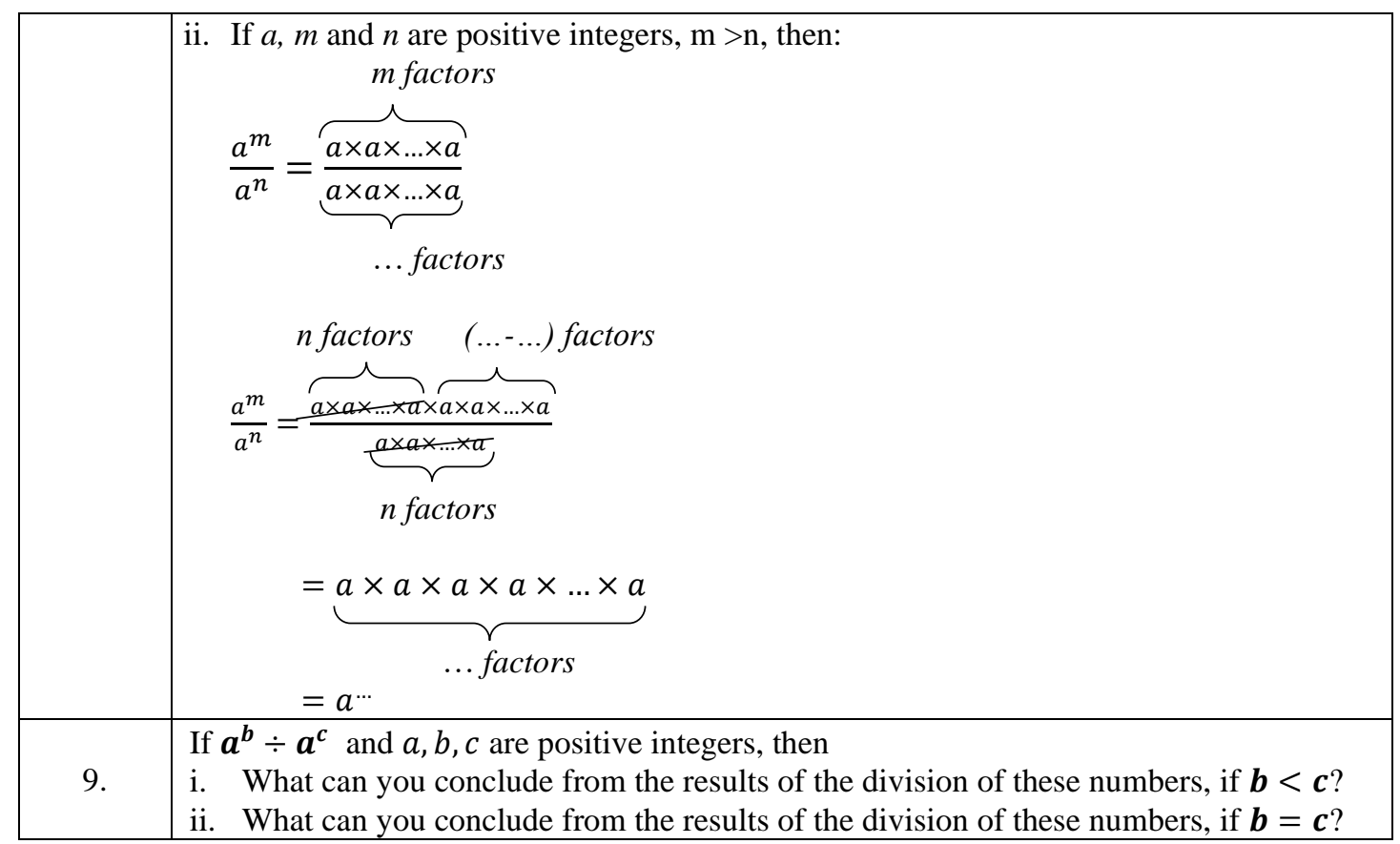

\section{Subject with Reflective Cognitive Style}

The following are 2 pictures of TPMP's answers from reflective students that we will use as references for interviews. Although both of them have reflective cognitive style, there are some differences in the answers given between them:

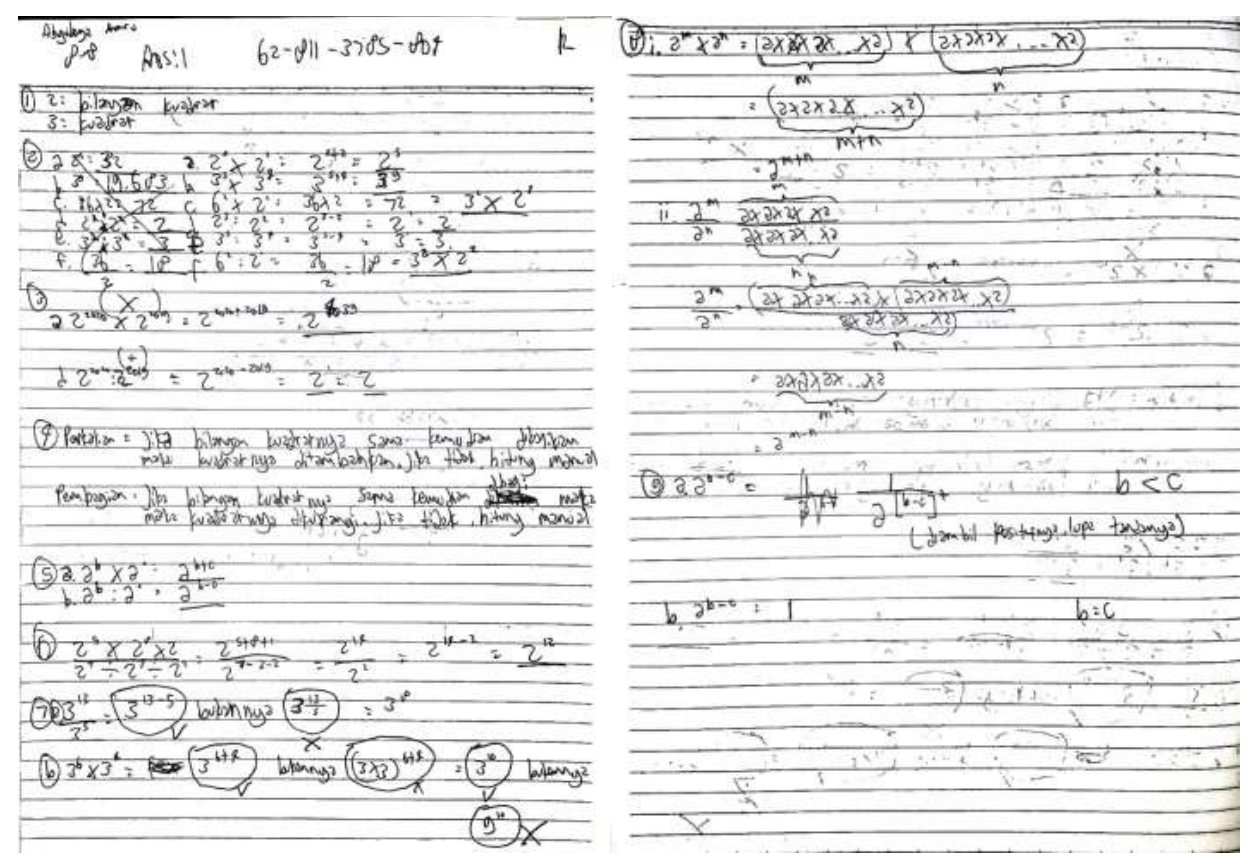

Figure 1. SR1's Answer

Then interviews were conducted with subject. The following are examples of interviews conducted based on students' answers to question number 2 of TPMP:

P : Do you feel difficult when working on question number 2?

SR1 : No mam.
P : For number 2a, how can u get $2^{5}$ ?

SR1 : By adding up the exponent

$\mathrm{P}$ : Please explain, how can the problem be done by that way?

SR1 : Because, $2^{3}=2 \times 2 \times 2$ then $2^{2}=$ $2 \times 2$ if we multiply then be $2^{3} \times 2^{2}=$ $2 \times 2 \times 2 \times 2 \times 2=2^{5}$. So, it can be solved by calculating the exponent. 

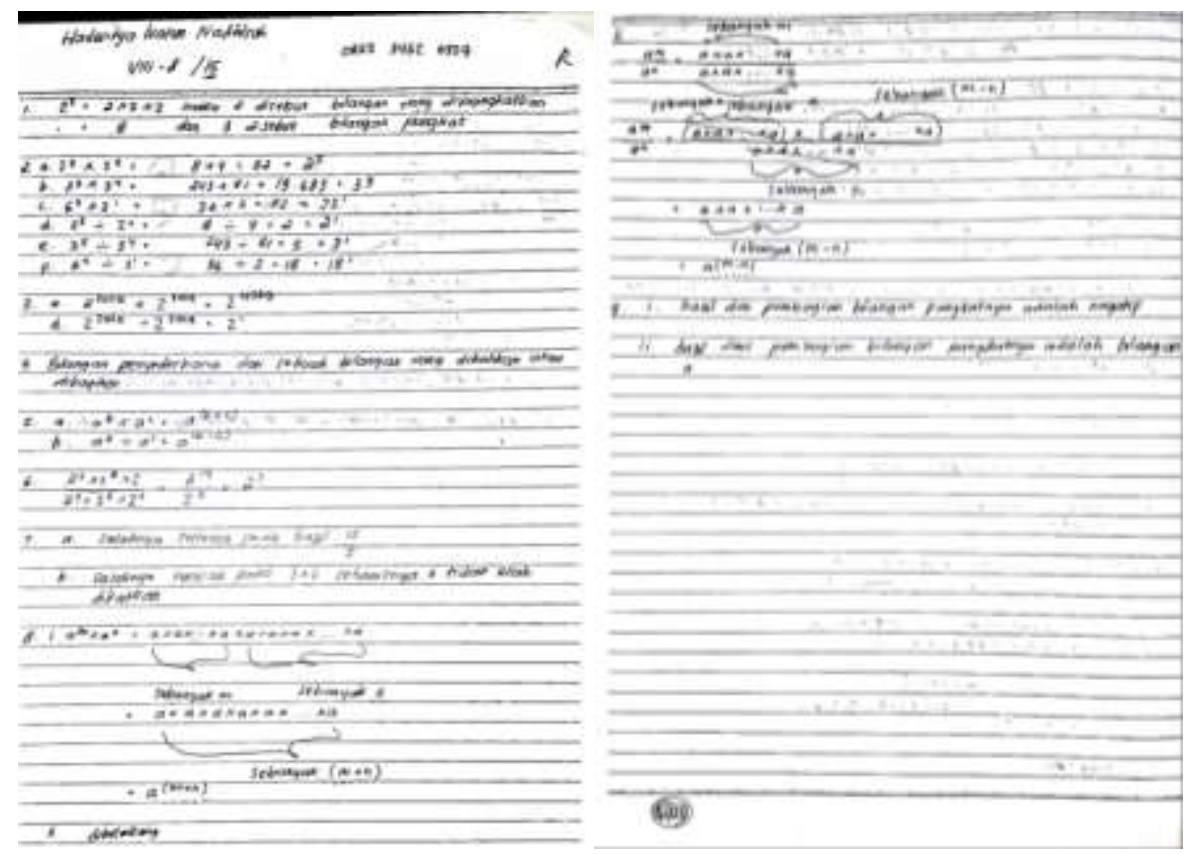

Figure 2. SR2's Answer

Based on the answer of SR2, then researcher ask subject about their understanding. For example her understanding at level image making. Following are examples of interviews conducted based on students' answers to question number 2 of TPMP:

P : Depends on your answer at question number 2, please explain your procedure to get the answer.

SR2 : First I look for the results of each exponential to be multiplied, after that I multiply the results. Then, I bring back them to exponential form

Based on the results of the answers SR1 and SR2 found some similarities and differences. in this discussion is based on the similarities of both, so researchers use the term SR, which means it represents SR1 and SR2.

- Primitive Knowing

Primitive knowing is the level of understanding of the initial knowledge that underlies a material, or can be said to be knowledge of the prerequisite material from the material to be studied. In the material multiplication and division of departing numbers, the initial material or prerequisite material that must be mastered is the definition of exponent as well as initial knowledge such as the term principal or base and exponent or exponent. The question used to describe this level is a matter of TPMP number 1. This question asks the subject to describe a number in the form of repeated multiplication, then write the results. It also asks the subject to label the components at the exponent earlier with the term principal or exponent.

Through the analysis of the answers SR can describe the exponent of $2^{3}$ correctly and write the results correctly $2^{3}=2 \times 2 \times 2=8$. SR can describe the position in the form of variables, for example, $a^{n}=a \times a \times \ldots \times a$ to $\mathrm{n}$ factors. SR is only able to describe the form of exponent without mentioning the conditions that must be met, namely the principal number is a real number and the exponent is a positive integer. In the case of labeling numbers 2 and 3 at $2^{3}$, SR incorrectly answers because SR claims he has never gained that knowledge before.

Thus, based on the description above it appears that SR does not have basic knowledge or prerequisites that are conceptually complete, but procedurally SR can describe some numbers into multiplicative repetition.

- Image Making

Image-making is the subject of either physical or mental actions to get new concepts. In this case, the problem used to describe the level of image-making is question number 2 .

Through the analysis of the answers to questions number 2 by SR, it is known that SR can answer the question well. Based on the SR answers it appears that SR is working on problem number 2 using the concept of repetitive multiplication. When working on question number 2, SR uses physical activity. SR tried to calculate the results of the appointment manually. 
In changing the exponent to the simplest form, SR can change to the correct form.

- Image Having

Data about image having level was obtained through interviews and analysis of the subject's answers to problem number 3 . In TPMP problem number 3 , subjects were asked to choose 2 out of 6 choices which according to the subject were the easiest multiplication and division questions.

Here are some conclusions from the SR concept description:

1. SR understands and understands the meaning of $2^{3}$ and they can translate it into repetitive multiplication and determine the outcome.

2. SR understands that the conditions needed for the concept of multiplication and division of numbers are the basis of both must be the same.

3. SR understands that in multiplication and division of numbers on the same basis can be done by adding up or subtracting the exponent.

- Property Noticing

At this level the subject can mention the properties of multiplication and division of numbers. The TPMP questions used to explore this knowledge are found in question number 4. Subjects are asked to write down what they know about multiplication operations and division of numbers.

Based on SR's answer, he can mention the properties of multiplication and division of exponent numbers correctly and in detail except that the terms principal or base and exponent or exponent are not used by SR. In this case, SR uses the term quadratic number. From this, it can be seen that, prior knowledge of SR or at the level of Primitive knowing he recognized exponent as quadratic. Even though the meaning of the square itself is only for exponent 2 .

- Formalizing

In question number 5 the subject is asked to write down the general form of the concept of multiplication and division of numbers. Problem TPMP number 6 asks students to use the concepts of multiplication and division of numerical exponents in solving an assignment problem.

SR can answer problem number 5 correctly. When interviewed SR was confused when asked questions related to variables replaced by a number. SR seems confused answering may or may not if the variable is replaced by a number. From this, it appears that SR can only write in variables, but SR does not fully understand the meaning of the variable.

In the answer to question number 6 , the SR subject can do the problem using the concept of multiplication correctly.

- Observing

At this level, the subject is expected to be able to observe an issue related to the concept of multiplication and division of numbers. To collect this ability, the subject is asked to solve problem number 7. Problem number 7 asks the subject to check the truth of a job in completing multiplication and division of numbers. Subjects were asked to assess whether the existing work was correct or still wrong. If wrong, the subject is asked to indicate the location of the error and then provide an alternative solution.

SR can do problem number $7 \mathrm{~b}$ well. SR can find the location of the error and at the same time able to show the correct solution. This means that SR can reflect itself on the concept of exponent multiplication.

- Structuring

SR can work on question number 8 correctly according to the question request. However, after the interview, it was seen that SR was unable to prove the concept of the appointment structurally. So, SR can be said not to reach the level of understanding structuring.

- Inventising

Based on the results of the answers and interviews, it appears that the SR did not reach the inventory level because the answers to the questions asked were not classified as new knowledge. Questions raised more directed to questions because they do not know or do not understand fully related to something that has been taught.

\section{Subject with Impulsive Cognitive Style}

The following are 2 pictures of TPMP's answers from impulsive students that we will use as references for interviews. Although both of them have impulsive cognitive style, there are some differences in the answers given between them: 


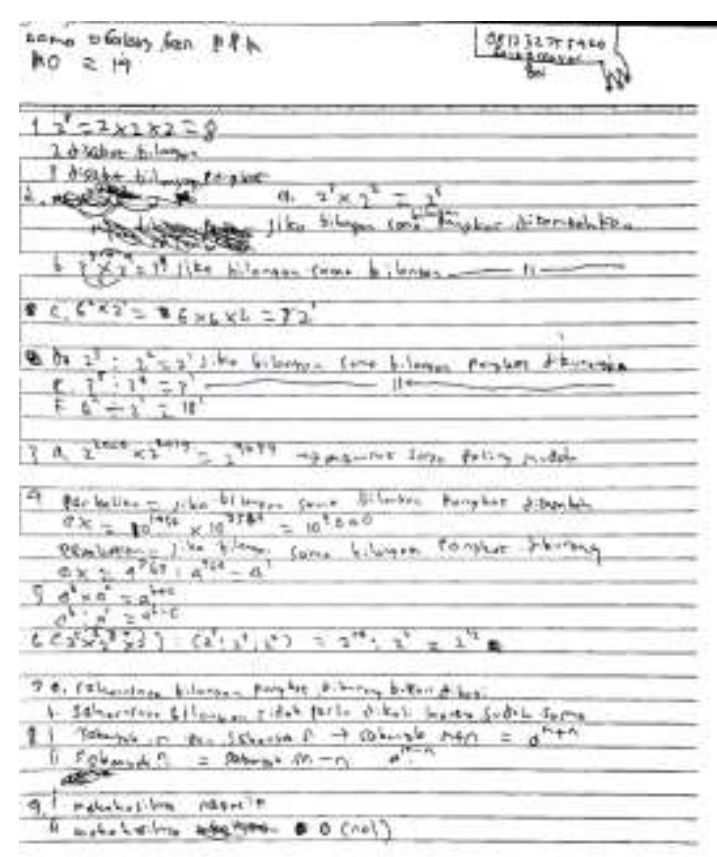

Figure 3. SI1's Answer

Then interviews were conducted with subject. The following are examples of interviews conducted based on students' answers to question number 2 of TPMP:

$\mathrm{P} \quad$ : Please explain your way to get answer the question number $2 \mathrm{a}$.

SI1 : first, we know that $2^{3}$ mean $2 \times 2 \times 2$, then $2^{2}$ mean $2 \times 2$ so, we can say that $2^{3} \times 2^{2}=2 \times$ $2 \times 2 \times 2 \times 2=2^{5}$.

$\mathrm{P} \quad$ : Do you have another way?

SI1 : No Mam, I just use that way.
P : How about number 2d?

SI1 : Because multiplication at the exponential can be done by adding up the exponent, then I think that division can be done by subtracting the exponent. But I did not spell out. It's just to see the results when subtracting the exponent and manually calculated the results are the same or not. It turns out the same. So I subtracted the exponential at the division of exponential.

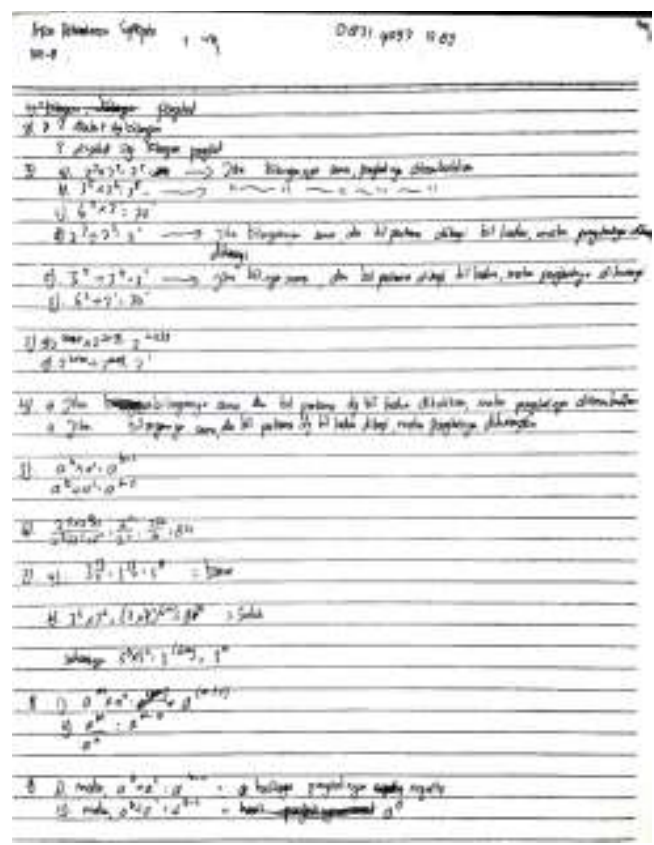

Figure 4. SI2's Answer 
Then interviews were conducted with subject. The following are examples of interviews conducted based on students' answers to question number 2 of TPMP:

$$
\begin{aligned}
& \text { P : Do you feel difficult when } \\
& \text { working on question number 2? } \\
& \text { SI2 : No mam. } \\
& \mathrm{P} \quad \text { : Okay, please explain, how can the } \\
& \text { problem be done by that way? }
\end{aligned}
$$

Based on the results of the answers SI1 and SI2 found some similarities and differences. In this discussion is based on the similarities of both, so researchers use the term SI, which means it represents SI1 and SI2.

- Primitive Knowing

Primitive knowing is the initial knowledge that underlies a material or can be said to be knowledge of the prerequisite material from the material to be studied. In the material multiplication and division of departing numbers, the initial material or prerequisite material that must be mastered can describe the form of numerical exponents in the form of repetitive multiplication as well as initial knowledge such as the term principal or base and exponent or exponent. The question used to describe this level is a matter of TPMP number 1. This question asks the subject to describe a exponent, then to write down the results. It also asks subjects to label the components at the exponent earlier with the term principal or exponent.

Through the analysis of the answers SI can describe the exponent of $2^{3}$ correctly and write the results correctly $2^{3}=2 \times 2 \times 2=8$. SI is not able to describe the position in the form of variables, for example $\mathrm{a}^{\mathrm{n}}=\mathrm{a} \times \mathrm{a} \times \ldots \times$ a to $n$ factors. SI is only able to describe the form of exponent without mentioning the conditions that must be met, namely the principal numbers are real numbers and the exponent is a positive integer. In terms of labeling numbers 2 and 3 in $2^{3}$, SI is still wrong in answering because SI claims to have never gotten that knowledge before, so SI calls it an exponent number. This is in line with the results of research by Wahyuni, et al. (2016) which states that one of the types of mistakes made by students in working on the material of departure is the Basic Error which is the basic concept error and Missing Information that is not being able to answer completely.

Thus, based on the description above it appears that SI does not have basic knowledge or complete prerequisites or in other words SI masters the material procedurally and has not fully understood conceptually.

\section{- Image Making}

Image-making is an activity subject to either physical or mental action to get a new concept. In this case, the problem used to describe the level of image-making is question number 2 . Through the analysis of the answers to questions number 2 by SI, it is known that SI can answer the questions well. SI does physical activity to find the concept of multiplication and division of exponent. The physical activity carried out by doing calculations manually to ensure the truth of the concepts he had built.

- Image Having

Image-making is an activity subject to either physical or mental action to get a new concept. In this case, the problem used to describe the level of image-making is question number 2 .

Here are some conclusions of the concept description that SI has:

1. SI procedurally understands and understands the meaning of $2^{3}$ and they can describe it in the form of repetitive multiplication and determine the results.

2. SI understands that the conditions needed to add or subtract the exponents of two numbers which are multiplied or divided are the basis of both must be the same.

- Property Noticing

At this level, the subject can mention the properties of the multiplication and division of numerical numbers. The TPMP questions used to explore this knowledge are found in question number 4. Subjects are asked to write down what they know about multiplication operations and division of numbers. Based on SI's answers, he can mention the properties of multiplication and division of numbers of exponent with good and truly only the terms principal or base numbers and exponent or exponents are not used by SI. SI uses the term exponent number. The advantage of SI's answer is that it includes examples in each explanation.

- Formalizing

In question number 5 the subject is asked to write down the general form of the concept of multiplication and division of numbers. Problem 
TPMP number 6 asks students to use the concept of multiplication in completing an assignment problem.

The result is that SI can use the concept of multiplication well if it is applied to a problem.

\section{- Observing}

At this level, the subject is expected to be able to observe a problem related to the concept of multiplication and division of numbers. To collect this ability, the subject is asked to solve problem number 7 . Problem number 7 asks the subject to check the truth of a job in completing multiplication and division of numbers. Subjects were asked to assess whether the existing work was correct or still wrong. If wrong, the subject is asked to indicate the location of the error and then provide an alternative solution.

SI states that the statement in question $7 \mathrm{a}$ is true, even though it should be false. This shows that SI experienced an error in having its image. Besides, it is also following Nasution (2010) which says that impulsive cognitive style people make decisions quickly without thinking deeply, so the answers given tend to be wrong.

The type of SI error in the preparation of question of the exponent is in accordance with the results of research by Wahyuni, et al. (2016) which states that one of the types of mistakes made by students in working on the material is the Basic Error, namely errors in the basic concepts and Partial Insight, namely errors caused by carelessness in calculations. In problem $7 \mathrm{~b}$ SI can answer correctly by showing the location of the error, giving reasons and alternative correct answers.

- Structuring

At this level, the subject is expected to be able to prove the concept in a structured way. The question used to collect the ability was question number 8 and an interview was conducted.

SI can do problem number 8 correctly according to the question request. However, after the interview, it was seen that SI was unable to prove the concept of the appointment structurally. So, SI cannot be said to reach the level of understanding structuring.

- Inventising

At this level, the subject is expected to be able to raise a question, which answers to these questions are the embryo of further knowledge. The question used to collect this question is question number 9 and an interview.

Based on the results of the answers and interviews, it can be seen that the SI subject did not reach the inventory level because the answers to the questions asked were not classified as new knowledge. Questions raised more directed to questions because they do not know or do not fully understand the concepts that have been taught.

\section{CONCLUSION}

Based on the analysis and discussion of the data obtained during the study, the researcher may draw some conclusions as follows:

1. SR at the primitive knowing level can procedurally describe numerical exponents in the form of repetitive multiplication, at the level of image making students use mental activities in building understanding related to multiplication and division of numbers on the same basis, at the image level having students have the picture that the multiplication of two numbers with the same base can be solved by adding up the exponents and the division can be done by subtracting the exponent, at the level of property noticing students can mention the properties of the multiplication and division of the exponent numbers with detail and correct, at the formalizing level students can generalize the concept of multiplication and division and can apply it to questions related correctly, at the observing level students reflect on the concepts that have been taught by observing a pro step several completion of multiplication and division of exponent numbers correctly, and reflective students have not been able to reach the level of structuring and inventising.

2. SI at the primitive knowing level as reflective students are able to describe numbers in the form of repetitive multiplication, at the level of image making impulsive students use mental and physical activities to build understanding related to multiplication and division of exponent, at the level of image having the same like a reflective student he has a picture that the multiplication of two numbers with the same base can be solved by adding up the exponent and the division can be done by subtracting the exponent, at the level of property noticing students can mention the properties of multiplication and division at exponent correctly but not as detailed as students reflective, at the level of formalizing impulsive students are able to generalize concepts and apply them to problems related to slight errors due to inaccuracy, at the observing level students reflect on the concepts that have been taught by doing observation of a procedural step in completing a multiplication of exponent correctly but is still wrong in the concept of division of exponent, and impulsive students as reflective students have not been able to reach the level of structuring and inventising. 
Conclusions present a summary of the description of the results and discussion, referring to the research objectives. Based on these two points, new ideas are developed which are the essence of the research findings.

\section{SUGGESTION}

Based on the study that has been done, there are suggestions as follows:

1. In this study, the questions given to students are not matched with indicators of the level of understanding based on the Pirie-Kieren theory that has been made, so that students' understanding data obtained is incomplete. Therefore for other researchers, it should consider making questions and ascertained matched the indicators that have been made, so the questions can increase student growth by the development of growth in understanding by Pirie-Kieren.

2. When giving a cognitive style that is MFFT, ask each observer (observer) to accept 1 student. The aim is to obtain accurate time and error score data, so that appropriate reflective and impulsive subjects are obtained.

3. In this study not only presented at the level determined by students but also presented at each level conducted by students. The results of understanding level research based on Pirie and Kieren's theory of understanding would be better if the conclusions also discussed the growth path of students who are dynamic and not linear in the form of images

\section{REFERENCES}

Abubakar, H. 2016. Influence of Reflective and Impulsive Cognitive Styles on Academic SelfEfficacy among Senior Secondary Students in. Dissertation. Nigeria: Ahmadu Bello University. (Online), (http://kubanni.abu.edu.ng), diunduh pada 10 November 2018.

Garagae, K. G. 2012. A Quest for Understanding in Mathematics Learning: Examining Theories of Learning. University of Botswana.

Mokwebu, D.J. 2013 An Exploration of the Growth in Mathematical Understanding of Grade 10 Learners. Polokwane: University of Limpopo.
Mousley, J. 2004. "An Aspect of Mathematical Understanding: the Notion of Connected Knowing". Proceeding of $28^{\text {th }}$ conference of the international group for the psychology of mathematics education. Vol. 3,pp. 377-384.

Nasution. 2010. Berbagai Pendekatan dalam Proses Belajar dan Mengajar. Jakarta: Bumi Aksara.

NCTM. 2000. Principles and Standart for School Mathematics. Reston, VA: National Council of Teacher of Mathematics.

Parameswaran, R. 2010 Expert Mathematicians' Approach to Understanding Definition, Vol. 20, Nomor 1, pp. 43-51.

Pinahayu, Eka A. R. 2015. Problematika Pembelajaran Matematika pada Pokok Bahasan Eksponen dan Alternatif Pemecahannya. Jurnal Formatif, 5(3): 182191.

Pirie, S. \& Kieren, T. 1994. Growth in Mathematical Understanding: How can We Characterise it and How can We Represent it? Educational Studies in Mathematics, Vol. 26, pp. 165-190.

Syafiqoh, N., Amin, S.M. \& Siswono, T.Y.E. 2018. Analysis of Student's Understanding of Exponential Concept: A perspective of PirieKieren Theory. MISEIC. IOP Conf. Series: Journal of Physics: Conf. Series 1108 (2018) 012022

Wahyuni, R., Subanji, \& Sisworo. 2016. Analisis Kesalahan Siswa dalam Menerapkan Aturan Eksponen. Prosiding Seminar Nasional Pendidikan Matematika, Vol. 1. ISSN 2528259X

Walle, J.A., Karp, S. K., \& Williams, J. M. B. 2013. Elementary and Middle School Mathematics Teaching Developmentally. USA: Pearson.

Weber, K. 2002. Developing Students' Understanding of Exponents and Logarithms. Proceedings of the Annual Meeting [of the] North American Chapter of the International Group for the Psychology of Mathematics Educations, pp. 1019-1027. 